\title{
Impact of Agricultural Cooperatives on Income of Households: The Case of Ejere District, Oromia National Regional State, Ethiopia
}

\author{
Naol Mammo ${ }^{1 *} \quad$ Milkessa Asfaw ${ }^{2} \quad$ Nigusu Abera ${ }^{3}$ \\ 1.Department of Business Administration, College of Business and Economics, Rift Valley University, Ethiopia \\ 2.Department of Agricultural Economics, College of Agriculture and Natural Resources, Ethiopia \\ 3.Department of Agricultural Economics, College of Agriculture and Natural Resources, Salale University, \\ Ethiopia
}

\begin{abstract}
Agricultural cooperative is widely considered as a vital foundation that can help smallholder farmers to overcome the constraints that hinder them from taking advantages of their business. The major concern of this study is, to evaluate the impact of agricultural cooperative on total annual income of participant households in Ejere district of West Shewa Zone, Ethiopia. To meet the objectives of study a total of 430 sample households were randomly interviewed. Descriptive statistics, logistic regression and propensity score matching were used to analyze data. The logistic regression output showed that access to extension services, marital status, clarity of cooperative objectives, perception and access to credit service were positively and significantly influenced the participation of household head in agricultural cooperative at $(\mathrm{P}<0.01)$ whereas access to market information and total livestock unit positively and significantly influenced the participation of household head in agricultural cooperatives at $(\mathrm{P}<0.05)$. Propensity score matching estimation result significant difference between agricultural cooperative participant and non-participant in terms of total annual income. That is, the total annual income of agricultural cooperative participants is $14,990.076$ Birr higher than that of non-participants. Thus, policy makers should focus on providing extension services, raising market information as well as increasing access to credit services of cooperatives in the study area.
\end{abstract}

Keywords: Annual income, Cooperatives, Impact, logistic, outcome

JEL: M2 L3 R2

DOI: $10.7176 / \mathrm{EJBM} / 13-9-03$

Publication date:May $31^{\text {st }} 2021$

\section{INTRODUCTION}

Most of Africa's poor hang on largely on agriculture for their livelihoods (IFAD, 2011), improving the yield, viability, and sustainability of the agricultural sector is debated to be the chief pathway out of poverty in the continent (Christiaensen \& Todo, 2013; Asfaw et al., 2012; Dawson et al., 2016). In spite of this point, the growth of agricultural sector in Africa has been lagging (Diao et al., 2012). Particularly the agricultural productivity in Sub Saharan Africa (SSA) remains stationary (Tittonell and Giller, 2013). Over the past four decades, while the productivity of the rest of the developing world improved by $4 \%$ agricultural productivity growth in SSA averaged only $2.4 \%$ (Dzanku et al., 2015).

In Ethiopia agriculture plays a crucial role in the economy. Agriculture share $40.2 \%$ of GDP, $80 \%$ of employment, and $70 \%$ of export earnings in the country (UNDP, 2015). Also, more than $80 \%$ of populations depend on agriculture to sustain their life and also as employment source (Negatu et al., 2016). Hence, the routine of this sector defines the destiny of the economy of the country. Nonetheless, smallholder farmers who are illiterate, living on the threshold between subsistence and poverty, dominate the sector. They depend on outdated technologies with access to credit deficiency, market information, improved technologies, functioning markets (for inputs, outputs, finance, consumer goods, and services, etc.) and other infrastructure (Alene and Hassan, 2006). Farmers can overcome those problems by acting cooperatively to obtain collective strength that they do not have individually, and in doing so, they find the pathway out of poverty and powerlessness (Bibby and Shaw, 2005). Hence, they need to get organized and cooperatives are an ideal, member-owned, business organization as it offers the institutional framework through which members control both production and marketing activities (Davis, 2008).

Several empirical studies show that agricultural cooperatives improve farm productivity through their influence on the adoption of productivity-enhancing technologies (Spielman et al., 2010; Abebaw and Haile, 2013) and by improving farm productivity (Abate et al., 2014). This improvement in agricultural productivity is important for enhancing farmer livelihood, reducing rural poverty, and increasing food security (Kassie et al., 2011; Asfaw et al., 2012; Shiferaw et al., 2014). Several studies also indicate that cooperative membership improves the commercialization behavior of smallholder farmers (Markelova and Mwangi, 2010). In addition to this, cooperatives can also reduce transaction costs and information asymmetry by strengthening farmers' negotiation ability (ILO, 2016; Trebbin, 2014). This will, in turn, increase the income of farmers (members) 
through their bargaining power, which increases the price of the product they produced and lowers the costs of purchased inputs.

Different studies (Coon, 2005; Wanyama et al., 2008; Getnet and Anullo, 2012; Ito et al., 2012; Verhofstadt and Maertens, 2014) also confirm the role of cooperatives in poverty reduction and in improving the livelihood of smallholder farmers. However, Ahmed and Mesfin (2017) reported there are also cases where collective actions did not improve farmers' situation Therefore; more research is required to show the role of agricultural cooperatives. Hence, the objective of study is to identify factors that influence farmers' decisions to join agricultural cooperatives and estimates the impact of agricultural cooperative membership on the total annual income of households in in the study area.

\section{RESERCH METHODOLOGY \\ Study Area Description}

Ejere district is one of the district west Shewa zone, in the Oromia National Regional State, Ethiopia. It is bordered on the south by the southwest Shewa zone, on the west by Dendi, on the northwest by Jeldu, on the north by Meta Robi, on the northeast by Ada'a berga and on the east by Walmara. The major town in Ejere is Ejere town, after which the district is named.

\section{Sampling Procedure and Sample Size}

The target populations of the study were agricultural cooperative participants (treatment group) and nonparticipants (control group) in Ejere district. In this study, two stage sampling techniques were employed to select the respondents. In the first stage, household heads are stratified into participant (treatment group) and nonparticipant household heads. In the second stage, 430 household heads were selected by using simple random sampling technique. Non-participant is used as control group to match with participant group. In this study, the sample size was determined based on the Gujarat (2003) as indicated below.

$$
\begin{aligned}
& \quad \boldsymbol{n} \geq \mathbf{5 0}+\mathbf{8 m} \\
& n=\text { sample size } \\
& m=\text { is number of independent variables }
\end{aligned}
$$

Based on the suggested explanatory variables about 215 agricultural cooperative participant household heads and 215 non-participants were interviewed for data collection. Totally about 430 households were interviewed.

\section{Data Type, Source \& Collection methods}

This study employed both qualitative and quantitative data types obtained from both primary and secondary source. Primary data was obtained by questionnaire methods. Secondary data were obtained through review of relevant literature from libraries, journals, websites and etc.

\section{Data Analysis Method}

Both descriptive statistical tools and econometric analysis propensity score matching (PSM) were employed.

To identify determinants of household participation in agricultural cooperative, logit model was employed. A logistic regression is performed to determine the joint effect of different independent variables on membership and to discover the intention why agricultural cooperatives participants are energetic in some of the sites and relatively low in others. The strength of association between an independent and the responses of interest are explained by odds ratio.

In most studies propensity score matching (PSM) method has been used to evaluate public policies/projects/programs. PSM matches each agricultural cooperatives participant household with a nonparticipant household that has almost the same likelihood of adopting any social programs to find the closest comparison group from a sample of nonparticipants to the sample of agricultural cooperatives participants.

In impact estimation PSM constructs a counterfactual comparison group based on a model of the probability of participating in the treatment, using observed characteristics. On the basis of this probability, participants are matched or propensity score, to non-participants for the impact evaluation.

In this study, different PSM matching algorithms was employed as well as fundamental assumptions of PSM was followed. Program participation (agricultural cooperatives participation) indicator $\boldsymbol{D} \boldsymbol{i}$ equals 1 if individual $\boldsymbol{i}$ participated and zero otherwise. The treatment effect for an individual i written as (Eq. 1):

$\mathrm{Ti}=\mathrm{Yi}(1)-\mathrm{Yi}(0)$

The fundamental evaluation problem arises because only one of the potential outcomes is observed for each individual i. Counter- factual outcome is also called unobserved outcome. The average treatment effect (ATT) is 
that the parameter that received the most devotion in appraisal literature, which is defined as (Eq. 2):

$$
\tau_{A T T}=E(\tau / D=1)=E[Y(1) / D=1]-E[Y(0) / D=1]
$$

As the counterfactual mean for those being treated $E[Y(1) / D=1]$ is not observed, one has to choose a proper substitute for it in order to estimate ATT. Using the mean outcome of untreated individuals $E[Y(0) / D=0]$ is in non-experimental studies usually not a good idea, because it is most likely that components which determine the treatment decision also determine the outcome variable of interest. Thus, the outcomes of individuals from treatment and comparison group would differ even in the absence of treatment leading to a 'self-selection bias'. For ATT it can be noted as (Eq. 3):

$$
E[Y(1) / D=1]-E[Y(0) / D=\tau A T T+E[Y(0) / D=1]-E[Y(0) / D=0]-----------[3]
$$

The variance between the left hand side of equation [3] and $\tau_{A T T}$ is the so-called 'self-selection bias'. The factual parameter $\tau_{A T T}$ is identified (Eq. 4):

$$
E[Y(0) / D=1]-E[Y(0) / D=0]=0
$$

Thus, in a program evaluation literature the effectiveness of matching estimators as a feasible estimator depends on two fundamental assumptions:

Conditional Independence Assumption [CIA]: This assumption imposes a restriction that choosing to participate in a program is purely random for similar individuals. Given a set of observable covariates (X) which are not affected by treatment, potential outcomes are independent of treatment assignment. This assumption implies that the selection is solely based on observable characteristics, and variables that influence treatment assignment and potential outcomes are simultaneously observed (Eq. 5).

$$
Y(0), Y(1) I I D / X, A X
$$

It should also be clear that conditioning on all relevant covariates is limited in case of a high dimensional vector $X$. The propensity score i.e. $P(D=1 / X)=P(X)$ the probability for an individual to participate in a treatment given observed covariates $X$, is one possible balancing score. The conditional independence assumption (CIA) based on the propensity score (PS) can be written as (Eq. 6):

$$
Y(0), Y(1) I I D / P(X), A X
$$

Common Support: Assumptions besides conditional independence (CIA) is the common support or overlap condition. The assumption is that $\mathrm{P}(\mathrm{x})$ (probabilities) lies between 0 and 1 . This restriction implies that the test of the balancing property is performed only on the observations whose propensity score belongs to the common support region of the propensity score of treated and control groups (Becker and Ichino, 2002). Individuals that fall outside the common support region would be excluded in the treatment effect estimation (Eq. 7).

$0<P(D=1 / X)=P(X)<1$

Common support ensures that individuals with the same characteristics have positive probability of being treated or not treated in the program.

Finally the PSM estimator for ATT can be written as (Eq. 8):

$T_{A T T}^{P S M}=E_{(P(X) / D=1)}\{E[Y(1) / D=1, P(X)]-E[Y(0) / D=0, P(X)]\}$ 
The explanation of the above PSM estimator is simply the mean difference in outcomes over the common support, appropriately weighted by the propensity score distribution of participants.

Choosing Matching Algorithm: PSM estimators differ not only in the way the neighborhood for each treated individual is defined and the common support problem is handled, but also with respect to the weights assigned to these neighbors.

Nearest Neighbor Matching: The most straightforward matching estimator is nearest neighbor (NN) matching. The individual from the comparison group is chosen as a matching partner for a treated individual that is closest in terms of propensity score.

Radius Matching: Caliper matching means that an individual from the comparison group is chosen as a matching partner for a treated individual that lies within a given caliper (propensity score range) and is closest in terms of propensity score (Caliendo and Kopeinig, 2008).

Stratification Matching: The idea of stratification matching is to partition the common support of the propensity score into a set of intervals (strata) and to calculate the impact within each interval by taking the mean difference in outcomes between treated and control observations.

Kernel Matching: use weighted averages of all individuals in the control group to construct the counterfactual outcome. Thus, one major advantage of these approaches is the lower variance which is achieved because more information is used. A drawback of these methods is that possibly observations are used that are bad matches.

Assessing the Matching Quality: Since we do not condition on all covariates but on the propensity score, it has to be checked if the matching procedure is able to balance the distribution of the relevant variables in both the control and treatment group. The basic idea of all procedures are to compare the situation before and after matching and check if there remain any differences after conditioning on the propensity score. If there are differences, matching on the score is not (completely) successful and remedial measures have to be done. The followings are common criteria to assess the matching qualities.

Standardized Bias: One suitable indicator to assess the distance in marginal distributions of the variables is the standardized bias (SB). For each covariate $X$ it is defined as the difference of sample means in the treated and matched control subsamples as a percentage of the square root of the average of sample variances in both groups. The standardized bias before is given by (Eq. 9):

$S_{\text {Before }}=\frac{X_{1}-B_{0}}{\sqrt{\left(V_{1}(X)-V_{0}(X)\right) * 0.5}} * 100$

The standardized bias after matching is given by (Eq. 10):

$S_{A f t e r}=\frac{X_{1 M}-z_{0 M}}{\sqrt{\left(V_{1 M}(X)-V_{0 M}(X)\right) * 0.5}} * 100$

Where $X 1(V 1)$ is the mean (variance) in the treatment group before matching and $X 0(V 0)$ the analogue for the control group. $X 1 M(V 1 M)$ and $X 0 M(V 0 M)$ are the corresponding values for the matched samples.

t-test: In order to check presence of significant differences in covariate for both groups a two-sample ttest were employed in most researches (Rosenbaum and Rubin, 1985). Differences are expected before matching, but the covariates should be balanced in both groups after matching and hence no significant differences should be found. The t-test might be preferred if the evaluator is concerned with the statistical significance of the results. The weakness at this time is that the bias decline before and after matching is not openly visible.

Joint Significance and Pseudo- $\boldsymbol{R}^{2}$ : Additionally, Sianesi (2004) suggests re-estimating the propensity score on the matched sample that is only on participants and matched nonparticipants and compare the pseudo$\mathrm{R} 2$ 's before and after matching. The pseudo- $R 2$ indicates how well the repressors $X$ explain the participation probability. There should be no systematic differences in the distribution of covariates between both groups after matching and therefore, the pseudo- $\mathrm{R}^{2}$ should be fairly low. Therefore, this study the necessary estimation techniques along with PSM method were used. It describes the average treatment effect; the common support regions; the matching algorithms and the matching quality are presented.

In this study, dependent variable is dichotomous that is designated by 1 for agricultural cooperative member household heads and 0 for non-member household heads. One outcome variable which is total annual income of the household head was used in the Propensity Score Matching (PSM) analysis. Total annual income refers to the total income in terms of money (Birr) that a household head earns in a year from different activities including selling of goods and services. 


\section{RESULT AND DISCUSSION}

Characteristics of the Respondents with respect to dummy variables

As indicated in Table 1, about $23.95 \%$ of total interviewed respondents were female-headed, whereas the remaining was male-headed. Small portion of the respondents $(19.77 \%)$ were single, whereas, the remaining were married. Concerning to the extension services, more than half $(56.28 \%)$ of the respondents had no access to this services About $38.37 \%$ of respondents have access to market information, where the remaining has no adequate market information. Though the respondents heard the existence of the cooperatives in their vicinity, about $64.65 \%$ of them haven't clear understanding about its objectives and advantages.

Table 1: Respondents Characteristics (Categorical variables)

\begin{tabular}{llll}
\hline Variable & Description & Frequency $(\mathbf{N}=430)$ & Percentage \\
\hline \multirow{2}{*}{ Sex } & Female & 103 & 23.95 \\
\cline { 2 - 4 } & Male & 327 & 76.05 \\
\hline \multirow{2}{*}{ Market Information } & Yes & 188 & 43.72 \\
\cline { 2 - 4 } & No & 242 & 56.28 \\
\hline Marital Status & Yes & 165 & 38.37 \\
\cline { 2 - 4 } & No & 265 & 61.63 \\
\hline COCO & Single & 85 & 19.77 \\
\cline { 2 - 4 } & Married & 345 & 80.23 \\
\hline Perception & Yes & 152 & 35.35 \\
\cline { 2 - 4 } & No & 278 & 64.65 \\
\hline Access to credit service & Yes & 182 & 42.33 \\
\cline { 2 - 4 } & No & 248 & 57.67 \\
\hline Nes & Yes & 193 & 64.88 \\
\cline { 2 - 4 } & No & 297 & 69.07 \\
\hline
\end{tabular}

$N=$ total number of respondents handled

Source: Computation from own Survey (2019)

Table-2 presents characteristics of respondents for continuous variables. Average age of respondent was about 39.62 years with minimum and maximum age of 20 and 63 years, respectively. This implies majority of the respondents are at productive stage which could be a good opportunity for agricultural cooperatives. The study also pointed out that the average landholding of household head was 2.1 ha with 0.5 and 10 ha of minimum and maximum size, respectively. In this study, livestock is measured in tropical livestock unit. The average livestock holding of respondents were about 5.3 TLU, with the minimum of 0 and maximum of 17 TLU. The average educational level and family size of the respondent were 5 and 3, respectively.

Table 2: Age, Land size and Educational level of Household Heads

\begin{tabular}{lllll}
\hline Variables & Mean & Std.Dev. & Minimum & Maximum \\
\hline Family size & 5.426 & 2.275 & 0 & 19 \\
Livestock (TLU) & 5.327 & 3.410 & 1 & 17 \\
Age & 39.623 & 10.466 & 20 & 63 \\
Educational Level & 2.856 & 2.553 & 0 & 12 \\
Land holding size & 2.107 & 1.211 & .49 & 10 \\
\hline
\end{tabular}

Source: Own computation from survey result, 2019

These characteristics of these respondents were tested as they are statistically significant difference based on some explanatory variables as shown in table 3 and 4 below. Agricultural cooperative participants have statistically significant difference based on access to extension services, market information, marital status, perception, access to credit service and clarity of cooperative objectives. 
Table 3: Agricultural cooperatives participant and non- participant (categorical variables)

\begin{tabular}{|c|c|c|c|c|c|c|c|c|}
\hline \multirow{3}{*}{ Variables } & \multirow{3}{*}{ Category } & \multicolumn{4}{|c|}{ Treatment } & \multirow{3}{*}{ Total } & \multirow{3}{*}{$x^{2}$} & \multirow{3}{*}{ P-value } \\
\hline & & \multicolumn{2}{|c|}{ Non-member } & \multicolumn{2}{|c|}{ Members } & & & \\
\hline & & $\mathrm{N}$ & $\%$ & $\mathrm{~N}$ & $\%$ & & & \\
\hline \multirow[t]{2}{*}{ SEX } & Female & 61 & 28.37 & 42 & 19.53 & 103 & \multirow{2}{*}{4.609} & \multirow{2}{*}{0.0320} \\
\hline & Male & 154 & 71.63 & 173 & 80.47 & 327 & & \\
\hline \multirow[t]{2}{*}{ ATES } & No & 132 & 61.40 & 56 & 26.05 & 188 & \multirow{2}{*}{54.591} & \multirow{2}{*}{0.0000} \\
\hline & Yes & 83 & 38.60 & 159 & 73.95 & 242 & & \\
\hline \multirow[t]{2}{*}{ AMI } & No & 110 & 51.16 & 55 & 25.58 & 165 & \multirow{2}{*}{29.748} & \multirow{2}{*}{0.0000} \\
\hline & Yes & 105 & 48.84 & 160 & 74.42 & 265 & & \\
\hline \multirow[t]{2}{*}{ MARST } & No & 74 & 34.42 & 11 & 5.12 & 85 & \multirow{2}{*}{58.198} & \multirow{2}{*}{0.0000} \\
\hline & Yes & 141 & 65.58 & 204 & 94.88 & 345 & & \\
\hline \multirow[t]{2}{*}{ PERCEPTION } & No & 134 & 62.33 & 48 & 22.33 & 182 & \multirow{2}{*}{70.46} & \multirow{2}{*}{0.0000} \\
\hline & Yes & 81 & 37.67 & 167 & 77.67 & 248 & & \\
\hline \multirow[t]{2}{*}{ ACRS } & No & 139 & 64.65 & 54 & 25.12 & 193 & \multirow{2}{*}{67.92} & \multirow{2}{*}{0.0000} \\
\hline & Yes & 76 & 35.35 & 161 & 74.88 & 237 & & \\
\hline \multirow[t]{2}{*}{$\mathrm{COCO}$} & No & 120 & 55.81 & 32 & 14.88 & 152 & \multirow{2}{*}{78.803} & \multirow{2}{*}{0.0000} \\
\hline & Yes & 95 & 44.19 & 183 & 85.12 & 278 & & \\
\hline
\end{tabular}

Table 4 showed as almost agricultural cooperative participants have the highest scores in total annual income, educational level and land holding size

Table 4: Agricultural cooperatives participant and non-participant (continuous variables)

\begin{tabular}{llllll}
\hline \multirow{2}{*}{$\begin{array}{l}\text { Variabl } \\
\text { es }\end{array}$} & $\begin{array}{l}\text { Agricultural Cooperatives Non-Participant } \\
(\mathbf{N = 2 1 5})\end{array}$ & $\begin{array}{l}\text { Agricultural Cooperatives Participant } \\
(\mathbf{N = 2 1 5})\end{array}$ & $\begin{array}{l}\text { P- } \\
\text { value }\end{array}$ \\
\cline { 2 - 5 } TLU & 5.08 & Std. Dev & Mean & Std. Dev & 0.130 \\
\hline TAIN & 4568.39 & 0.214 & 5.57 & 0.248 & 0.000 \\
\hline Age & 39.5 & 72.480 & 20533.16 & 83.297 & 0.99 \\
\hline Educ & 2.34 & 0.714 & 39.62 & 0.714 & 0.000 \\
\hline LHS & 1.96 & 0.169 & 0.37 & 0.712 & 0.014 \\
\hline FMS & 5.56 & 0.073 & 2.25 & 0.089 & 0.211 \\
\hline
\end{tabular}

Factors Influencing Household Head participation in Agricultural Cooperatives

To identify factors determining household head participation in agricultural cooperatives logistic regression were employed. Output of logistic regression estimation is given in (Table 5) and only the significant variables and were discussed.

The overall significance and fitness of the logistic model is determined by its chi-square value. The chi-square value is $\operatorname{Pr}=0.0000$, shows as the explanatory variable can significantly predict the dependent variables. Robust standard error was used to minimize the problem of heteroskedasticity.

Logistic estimation output given in Table 5, revealed that access to extension services, marital status, clarity of cooperative objectives, perception, access credit services, total livestock unit and market information accessibility were significantly and positively influenced household participation in agricultural cooperatives. This implies that these variables were positively associated with the log of odds of household participation in agricultural cooperatives. These variables make households more likely to participate in agricultural cooperatives. Access to extension services, clarity of cooperative objectives, perception, access to credit services, land holding size and marital status are most significant at significance level of $\mathrm{P}<0.01$, and total livestock unit and access to market information for agricultural cooperatives were significant at 5\% significance level. 
Table 5: Logistic estimates for determinants factors of participation in agricultural cooperatives

Logistic Regression

$$
\begin{aligned}
& \text { Number of obs }=430 \\
& \text { Wald chi2(12) }=120.13 \\
& \text { Prob }>\text { chi2 }=0.0000
\end{aligned}
$$

Log pseudo likelihood $=-179.81$

$$
\text { Pseudo R2 }=0.3967
$$

\begin{tabular}{lllll}
\hline Treatment & Odds Ratio & Robust Std.Err. & $\mathbf{Z}$ & $\mathbf{P}>|\mathbf{z}|$ \\
\hline Sex & 1.3515 & 0.42495 & 0.96 & 0.338 \\
Family size & 0.9282 & 0.05628 & -1.23 & 0.219 \\
Access to Ext. service & 3.2900 & 0.8960 & 4.37 & 0.000 \\
Access to Mkt inf. & 1.9641 & 0.5439 & 2.44 & 0.015 \\
Marital status & 9.7781 & 4.6601 & 4.78 & 0.000 \\
Clarity of Co. & 3.3687 & 0.9748 & 4.20 & 0.000 \\
Perception & 3.2776 & 0.9293 & 4.19 & 0.000 \\
Access to credit & 3.3083 & 0.9085 & 4.36 & 0.000 \\
TLU & 1.0876 & 0.0414 & 2.21 & 0.027 \\
Age & 0.9985 & 0.0135 & -0.11 & 0.911 \\
EDLEV & 1.0613 & 0.06348 & 0.99 & 0.320 \\
LHS & 1.3594 & 0.1434 & 1.56 & 0.871 \\
cons & 0.0019 & 0.0081 & -6.51 & 0.000 \\
\hline
\end{tabular}

Access to Extension Services (ATES): This variable influence household head membership to agricultural cooperatives positively and significantly at $(\mathrm{p}<1 \%)$. This revealed, other things remains constant, the log of odds ratio of being member to the agricultural cooperatives was about 3.3 times greater for households with access to cooperative related extension services than those households without such services. Thus, household heads with better access to extension services on agricultural cooperatives has a positive attitude towards agricultural cooperatives. This result is consistent with empirical findings of Kassahun and Omer (2019) and Bernard et al. (2013).

Access to Market Information (AMI): The result of analysis has found that access to market information for products of agricultural cooperatives has a positive and significant association at $(\mathrm{p}<5 \%)$ with household heads participation in agricultural cooperatives. Holding other variables constant, log of odds ratio for household head with access to market information on agricultural cooperatives is 1.96 times greater compared to that of household head with no access to market information on agricultural cooperatives. This implies that household head with access to market information are more likely to engage in agricultural cooperatives membership than households without access to market information. Study made by Dejen and Matthews (2016) and Zeweld et al. (2013) supports this empirical finding.

Marital Status of Household Head (MARST): positively and significantly associated to the housed heads participation in agricultural cooperatives at $(\mathrm{p}<1 \%)$. This indicates married people were more likely to participate in agricultural cooperatives. All other things being equal, the result revealed that log of odds ratio of married household heads to a member of agricultural cooperatives was about 9.46 times greater than single household head. Also studies of Dagne et al. (2015) support as marital status has a positive and significant association with farmer's decision to enroll in a farmer group.

Clarity of cooperatives objectives (COCO): It is also not surprising to find that households that know more about objectives of agricultural cooperatives are more likely to participate in the agricultural cooperative activities. As inferred from the value of odds ratio, those households who have more clarity on cooperative objectives was 3.34 times more likely to become a member of agricultural cooperatives as compared to household without clarity of cooperative objectives, ceteris paribus. The empirical research finding of Zeweld et al. (2013) also supports this result.

Perception: positively and significantly affect agricultural cooperatives membership at $(\mathrm{p}<1 \%)$. The result of odds ratio pointed out that, household head who have a positive perception about agricultural cooperatives was 3.28 more likely to engage in agricultural cooperatives activities as members than household head with ambiguous perceptions about agricultural cooperatives. The research of Gashaw and Kibret (2018) also supports this positive association. Moreover, the empirical research findings of Dejen and Matthews (2016) confirmed as perception of households increases farmers' cooperative membership in West Shewa zone, Ethiopia.

Total Livestock Unit (TLU): This variable is positively and significantly associated with household heads participation in agricultural cooperatives at $(\mathrm{p}<5 \%)$. This implies that for each one point increase in total livestock unit, leads to 1.09 increments in odds of household heads to become agricultural cooperatives member. The empirical research findings of Dagne et al. (2015); Abebaw and Haile (2013) and Francesconi and Wouterse (2011) supports this result. 


\section{Impact of Agricultural Cooperatives on Income of Households}

Estimation of the Propensity Scores

The first stage in the propensity score matching is to estimate the probability of being agricultural cooperative participant. Results presented in Table 6 below shows the estimated model for propensity score matching estimation using pscore command.

Table 6: Estimation of the propensity score

Estimation of the propensity score

Iteration 0: $\log$ likelihood $=-298.05329$

Iteration 1: $\log$ likelihood $=-190.70603$

Iteration 2: $\log$ likelihood $=-180.60348$

Iteration 3: $\log$ likelihood $=-180.09107$

Iteration 4: $\log$ likelihood $=-180.08908$

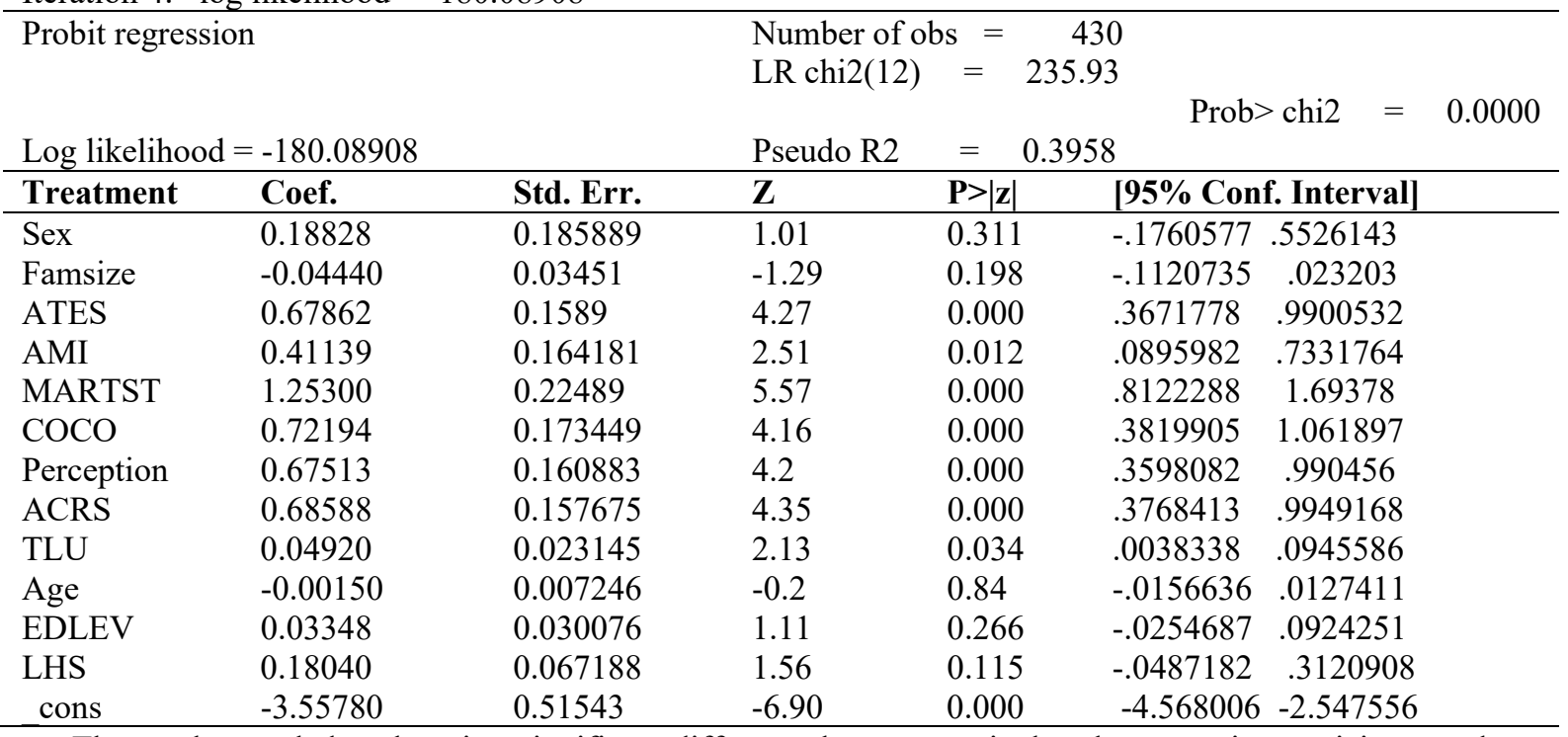

The result revealed as there is a significant difference between agricultural cooperative participant and nonparticipant in terms of six explanatory variables. These variables are access to extension services, access to market information, marital status, and clarity on cooperatives objectives, perception, access credit services and total livestock unit.

\section{Common Support Region}

The final number of blocks is 5 . This number of blocks ensures that the mean propensity score is not different for treated and controls in each blocks. The balancing property is satisfied. The region of common support is $[.02260519, .99467785]$ implying that the two groups share the same characteristics in these interval (figure 1).

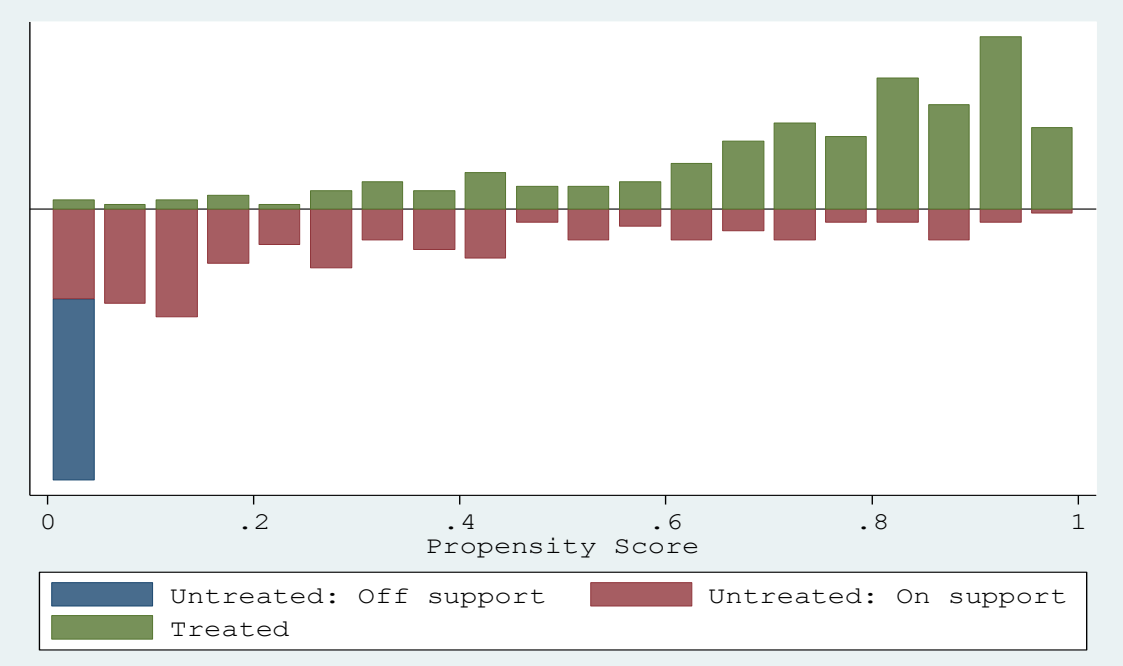

Figure 1: Propensity score distribution for treated and untreated in agricultural cooperatives non-Participant considering common support option 


\section{Matching Quality}

After choosing the best performing matching algorithm the next task is to check the balancing of propensity and covariates. The main purpose of the propensity score estimation is to balance the distributions of relevant variables in both groups. The balancing powers of the estimations are ascertained by considering different test methods such as the reduction in the mean standardized bias between the matched and unmatched households, equality of means using $t$-test and chi-square test for joint significance for the variables used.

In this study, mean standardized bias before and after matching are shown in Table 7 with the total bias reduction obtained by the matching procedure. It is evident that sample differences in the unmatched data significantly exceed those in the samples of matched cases. The process of matching those creates a high degree of covariate balance between the treatment and control samples that are ready to use in the estimation procedure. Similarly, the $t$-values indicated that before matching six covariates were exhibited statistically significant differences, while after matching all the variables have statistically insignificant differences in terms of six explanatory variables (Table 7). Besides, the standardized mean is below the critical level of $20 \%$ suggested by Rosenbaum and Rubin (1983).

Table 7: Propensity score and covariate balance

\begin{tabular}{|c|c|c|c|c|c|c|c|}
\hline Variables & $\begin{array}{l}\text { Unmatched } \\
\text { Matched }\end{array}$ & $\begin{array}{l}\text { Mean } \\
\text { Treated }\end{array}$ & Control & \%bias & $\begin{array}{l}\text { \%reduct } \\
\text { \%bias }\end{array}$ & $\begin{array}{l}\mathrm{t} \text {-test } \\
\mathrm{t}\end{array}$ & $\mathrm{p}>|\mathrm{t}|$ \\
\hline Sex & $\begin{array}{l}\mathrm{U} \\
\mathrm{M}\end{array}$ & $\begin{array}{l}0.80465 \\
0.80465 \\
\end{array}$ & $\begin{array}{l}0.71628 \\
0.8\end{array}$ & $\begin{array}{l}20.8 \\
1.1 \\
\end{array}$ & 94.7 & $\begin{array}{l}2.15 \\
0.12 \\
\end{array}$ & $\begin{array}{l}0.032 \\
0.904 \\
\end{array}$ \\
\hline Famsize & $\begin{array}{l}\mathrm{U} \\
\mathrm{M}\end{array}$ & $\begin{array}{l}5.2884 \\
5.2884 \\
\end{array}$ & $\begin{array}{l}5.5628 \\
5.5953 \\
\end{array}$ & $\begin{array}{l}-12.1 \\
-13.5 \\
\end{array}$ & -11.9 & $\begin{array}{r}-1.25 \\
-1.54 \\
\end{array}$ & $\begin{array}{l}0.212 \\
0.124 \\
\end{array}$ \\
\hline ATES & $\begin{array}{l}\mathrm{U} \\
\mathrm{M} \\
\end{array}$ & $\begin{array}{l}0.73953 \\
0.73953 \\
\end{array}$ & $\begin{array}{l}0.38605 \\
0.72558 \\
\end{array}$ & $\begin{array}{l}76.1 \\
3.0 \\
\end{array}$ & 96.1 & $\begin{array}{l}7.89 \\
0.33 \\
\end{array}$ & $\begin{array}{l}0.000 \\
0.744 \\
\end{array}$ \\
\hline AMI & $\begin{array}{l}\mathrm{U} \\
\mathrm{M} \\
\end{array}$ & $\begin{array}{l}0.74419 \\
0.74419 \\
\end{array}$ & $\begin{array}{l}0.48837 \\
0.74884 \\
\end{array}$ & $\begin{array}{l}54.4 \\
-1.0 \\
\end{array}$ & 98.2 & $\begin{array}{l}5.64 \\
-0.11 \\
\end{array}$ & $\begin{array}{l}0.000 \\
0.912 \\
\end{array}$ \\
\hline MARST & $\begin{array}{l}\mathrm{U} \\
\mathrm{M} \\
\end{array}$ & $\begin{array}{l}0.94884 \\
0.94884 \\
\end{array}$ & $\begin{array}{l}0.65581 \\
0.92093 \\
\end{array}$ & $\begin{array}{l}78.9 \\
7.5 \\
\end{array}$ & 90.5 & $\begin{array}{l}8.19 \\
1.17 \\
\end{array}$ & $\begin{array}{l}0.000 \\
0.242 \\
\end{array}$ \\
\hline $\mathrm{COCO}$ & $\begin{array}{l}\mathrm{U} \\
\mathrm{M} \\
\end{array}$ & $\begin{array}{l}0.85116 \\
0.85116 \\
\end{array}$ & $\begin{array}{l}0.44186 \\
0.89302 \\
\end{array}$ & $\begin{array}{l}94.5 \\
-9.7 \\
\end{array}$ & 89.8 & $\begin{array}{l}9.80 \\
-1.30 \\
\end{array}$ & $\begin{array}{l}0.000 \\
0.195 \\
\end{array}$ \\
\hline Perception & $\begin{array}{l}\mathrm{U} \\
\mathrm{M}\end{array}$ & $\begin{array}{l}0.77674 \\
0.77674\end{array}$ & $\begin{array}{l}0.37674 \\
0.75814\end{array}$ & $\begin{array}{l}88.3 \\
4.1\end{array}$ & 95.3 & $\begin{array}{l}9.16 \\
0.46\end{array}$ & $\begin{array}{l}0.000 \\
0.649\end{array}$ \\
\hline ACRS & $\begin{array}{l}\mathrm{U} \\
\mathrm{M} \\
\end{array}$ & $\begin{array}{l}0.74884 \\
0.74884 \\
\end{array}$ & $\begin{array}{l}0.35349 \\
0.79535 \\
\end{array}$ & $\begin{array}{l}86.4 \\
-10.2 \\
\end{array}$ & 88.2 & $\begin{array}{l}8.96 \\
-1.15 \\
\end{array}$ & $\begin{array}{l}0.000 \\
0.251 \\
\end{array}$ \\
\hline TLU & $\begin{array}{l}\mathrm{U} \\
\mathrm{M}\end{array}$ & $\begin{array}{l}5.5752 \\
5.5752 \\
\end{array}$ & $\begin{array}{l}5.0773 \\
5.2418 \\
\end{array}$ & $\begin{array}{l}14.6 \\
9.8 \\
\end{array}$ & \multirow[t]{2}{*}{33.0} & $\begin{array}{l}1.52 \\
1.07 \\
\end{array}$ & $\begin{array}{l}0.030 \\
0.285 \\
\end{array}$ \\
\hline Age & $\begin{array}{l}\mathrm{U} \\
\mathrm{M}\end{array}$ & $\begin{array}{l}39.623 \\
39.623\end{array}$ & $\begin{array}{l}39.623 \\
38.80\end{array}$ & $\begin{array}{l}0.0 \\
5.9\end{array}$ & & $\begin{array}{l}0.00 \\
0.84\end{array}$ & $\begin{array}{l}1.000 \\
0.404\end{array}$ \\
\hline EDLEV & $\begin{array}{l}\mathrm{U} \\
\mathrm{M}\end{array}$ & $\begin{array}{l}3.3721 \\
3.3721 \\
\end{array}$ & $\begin{array}{l}2.3395 \\
3.5721 \\
\end{array}$ & $\begin{array}{l}41.2 \\
-8.0 \\
\end{array}$ & 80.6 & $\begin{array}{l}4.28 \\
-0.71 \\
\end{array}$ & $\begin{array}{l}0.140 \\
0.480 \\
\end{array}$ \\
\hline LHS & $\begin{array}{l}\mathrm{U} \\
\mathrm{M}\end{array}$ & $\begin{array}{l}2.2506 \\
2.2506\end{array}$ & $\begin{array}{l}1.9636 \\
2.2221\end{array}$ & $\begin{array}{l}23.8 \\
2.4\end{array}$ & 90.1 & $\begin{array}{l}2.47 \\
0.24\end{array}$ & $\begin{array}{l}0.114 \\
0.811\end{array}$ \\
\hline
\end{tabular}

Furthermore, low pseudo-R2 (0.018) and the insignificant likelihood ratio tests support the hypothesis that both groups have the same distribution in covariates after matching (see Table 8). This result clearly shows that the matching procedure is able to balance the characteristics in the treated and the matched comparison groups. This allowed compare the intended outcomes for participants with those of a comparison groups sharing a common support. Therefore, results were used to evaluate the impact of agricultural cooperatives on total annual income of households having similar observed characteristics.

Table 8: Matching Quality with Pseudo $\mathbf{R}^{2}$

\begin{tabular}{lllllllll}
\hline Sample & PsR2 & LR chi2 & $\mathrm{p}>$ chi2 & Mean Bias & Med Bias & B & R & \%Var \\
\hline Unmatched & 0.36 & 235.93 & 0.000 & 49.3 & 47.8 & $175.4^{*}$ & $0.46^{*}$ & 40 \\
\hline Matched & 0.018 & 10.78 & 0.55 & 6.5 & 7.7 & $31.8^{*}$ & 1.75 & 60 \\
\hline
\end{tabular}

* If $\mathrm{B}>25 \%$, R outside $[0.5 ; 2]$

\section{Matching Algorithms}

The alternative matching estimators (algorithms) were applied in matching the treatment and control households in the common support region. The following result (Table 9) shows that agricultural cooperative participation does have a significant impact on household income by the nearest-neighborhood matching method at 5 percent 
level of significance $(t=123.996)$. The average treatment effect of the treated (ATT) on total annual income for agricultural cooperative participant household head was Birr 14,990.076. Agricultural cooperative participants are on average earns Birr 14,990.076more as compared to non-participants. The average treatment effect using stratification matching result shows Birr 15,091.097more annual income for agricultural cooperative participant household heads as compared to non- participant. The impact is significant at 5 percent level $(t=168.504)$. Furthermore, the ATT using radius matching result shows an increased impact $(15,127.065)$ more annual income significantly $(t=79.117)$ for agricultural cooperative participant household heads. Looking in to the average treatment effect using kernel matching result is consistent with earlier findings. The result of this matching algorithm shows that participation in agricultural cooperative increases total annual income of household heads by Birr 15,075.628at a 5\% significance level. This result was quite similar with nearest neighbor, radius and stratification matching methods.

Table 9: Different matching algorithm results (ATT difference b/n control \& treated group) Total Annual Income (TOAIN)

\begin{tabular}{|c|c|c|c|c|c|c|}
\hline Matching algorithm & $\begin{array}{ll}\text { No. } & \text { of } \\
\text { treated } & \\
\end{array}$ & $\begin{array}{l}\text { no. of } \\
\text { control }\end{array}$ & ATT (Birr) & Std. Err & t-value & $\begin{array}{l}\text { Total bias } \\
\text { reduction }\end{array}$ \\
\hline Kernel Matching & 215 & 175 & 15075.628 & 102.830 & $\begin{array}{l}158.27 \\
6\end{array}$ & 0.85 \\
\hline Nearest Neighbor Matching & 42 & 40 & 14990.076 & 130.573 & $\begin{array}{l}123.99 \\
6 \\
\end{array}$ & 0.86 \\
\hline Radius Matching & 215 & 75 & 15127.065 & 206.367 & 79.117 & 0.85 \\
\hline Stratification Matching & 215 & 175 & 15091.097 & 96.681 & $\begin{array}{l}168.50 \\
4\end{array}$ & 0.84 \\
\hline
\end{tabular}

Thus, all matching algorithms used above gives similar results. The maximum average total annual income because of agricultural cooperative participation in these matching algorithms was Birr 15,127.065 while the minimum was Birr 15,075.628. All results were statistically significant at one percent.

The final choice of a matching estimator was guided by criteria of matched samples and reduced bias. Matching estimator which results large matched sample size and greater bias is preferable. In line with these criteria of matching quality, nearest-neighborhood matching method was found to be the best matching algorithm for the data. Thus, controlling for other explanatory variables, the propensity score matching model using the nearest neighbor matching estimator indicates the existence of a positive and significant additional total annual income of Birr 14990.076 compared to agricultural cooperative non-participants.

Average Treatment Effect on the Treated: the PSM analysis using the nearest neighbor matching estimator indicates the existence of a positive additional significant total annual income of Birr 14,990.076 for agricultural cooperative participants compared to non- participants group (Table 9).

Checking Robustness of Average Treatment Effect

There are several ways to check robustness of the findings (average treatment effect). In this study the consistency of result of different matching methods to compared. The study showed that findings with different matching techniques are quite consistent (Table 9); this implies that findings are assumed to be more reliable. In all matching estimation the impact of agricultural cooperative on household's total annual income were significant.

\section{CONCLUSION AND RECOMMENDATION \\ Conclusion}

This paper examined the impact of agricultural cooperative on total annual income of households in Ejere district of Oromia National Regional State, Ethiopia. The study employed two stage sampling techniques to select 430 sampled households. Descriptive and econometric models were employed to analysis the data. The result of logistic regression revealed that access to extension services, access to market information, marital status, clarity of cooperative objectives, perception, access to credit and total livestock unit have a positive and significant association with household head participation in agricultural cooperative in the study area. The study demonstrated that agricultural cooperative has a significant contribution in increasing total annual income of participant households. Agricultural cooperative participants earned Birr 14,990.076 more total annual income than nonparticipants. Agricultural cooperative participant households were significantly different from non-participants in terms of total annual income. This result revealed, in agriculture dependent areas, agricultural cooperative has a lion share in improving the livelihoods of the participant households. This provides an encouraging signal for policy makers and implementers, and funding agents working on agricultural cooperatives.

\section{Recommendation}

In order to realize the intended outcomes of agricultural cooperatives, future development strategies should 
consider on how to: clearly advocating the objective of agricultural cooperatives, providing extension services on agricultural cooperatives management, improve awareness of households towards access to credit services and having more of livestock increases participation of households in different agricultural cooperatives. Therefore, strengthening agricultural cooperatives have a great value for improvement of the livelihood of households. This study limited its scope with the direct effects of the agricultural cooperatives intervention on household income. Therefore, further studies taking the other livelihood indicators in to consideration is necessary to extend the research work.

\section{ACKNOWLEDGEMENTS}

We acknowledge all people who are involved in this research study. Specially, our gratitude goes to sampled farmers who give their precious time and participated in this research.

\section{CONFLICT OF INTEREST}

The author declares that there is no conflict of interests regarding the publication of this manuscript.

\section{REFERENCES}

ABATE G., FRANCESCONI G. \& GETNET K. (2014). Impact of agricultural cooperatives on Smallholders' technical efficiency: empirical evidence from Ethiopia. Ann Public Coop Econ 85(2):257-286. doi:10.1111/apce.12035

ABEBAW D \& HAILE MG (2013). The impact of cooperatives on agricultural technology adoption: empirical evidence from Ethiopia. Food Policy 38:82-91, http://dx.doi.org/10.1016/j.foodpol.2012.10.003

AHMED M. \& MESFIN H. (2017). The impact of agricultural cooperatives membership on the wellbeing of smallholder farmers: empirical evidence from eastern Ethiopia. Agricultural and Food Economics, 5(1), 6. Doi: https://doi.org/10.1186/s40100-017-0075-z

ALENE AD \& HASSAN RM (2006). The efficiency of traditional and hybrid maize production in eastern Ethiopia: an extended efficiency decomposition approach. Journal of African Economies, 15(1), 91-116. doi:10.1093/jae/ej1020

ASFAW S, SHIFERAW B, SIMTOWE F \& LIPPER L (2012) Impact of modern agricultural technologies on smallholder welfare: evidence from Tanzania and Ethiopia. Food Policy 37(3):283-295, http://dx.doi.org/10.1016/j.foodpol.2012.02.013

BECKER S. O. \& ICHINO A. (2002). Estimation of average treatment effects based on propensity scores. The stata journal, 2(4), 358-377.

BERNARD T, ABATE GT \& LEMMA S (2013) Agricultural cooperatives in Ethiopia: results of the 2012 ATA baseline survey. International Food Policy Research Institute, Washington DC, doi=10. 1.1.352.7458\&rep $=$ rep $1 \&$ type $=$ pdf

BIBBY A \& SHAW L (2005). Making a difference: cooperative solution to global poverty. Cooperative College for the Department of International Development, Manchester

CALIENDO M \& KOPEINIG S (2008). Some practical guidance for the implementation of propensity score matching. J Econ Surv 22(1):31-72. doi:10.1111/j.1467-6419.2007.00527.x

CHRISTIAENSEN L. \& TODO Y. (2013). Poverty reduction during the rural-urban transformation-the role of the missing middle. The World Bank.

COON R. C. \& LEISTRITZ F. L. (2005). Economic contribution North Dakota cooperatives make to the state economy (No. 1193-2016-94303). Economic impacts of coffee farmers in Ethiopia," Agriculture in an Interconnected World Universita Degli Studi Di Miland, 8-14,

DAVIS R. S. (2008). Conditional Preemption, Commandeering, and the Values of Cooperative Federalism: An Analysis of Section 216 of EPAct. Columbia Law Review, 404-451. http://www.jstor.org/stable/40041761

DAWSON N, MARTIN A \& SIKOR T (2016). Green revolution in Sub-Saharan Africa: implications of imposed innovation for the wellbeing of rural smallholders. World Dev 78:204-218, http://dx.doi.org/10.1016/j.worlddev.2015.10.008

DEJEN D. \& MATTHEWS H. (2016). “A study on factors affecting farmers' cooperative membership increment in Bench Maji zone, south-western Ethiopia," Journal of developing country studies, Vol.6, No.2.

DIAO X, THURLOW J, BENIN S \& FAN S (eds) (2012). Strategies and priorities for African agriculture: economy wide perspectives from country studies.

DZANKU FM, JIRSTRÖM M \& MARSTORP H (2015) Yield gap-based poverty gaps in rural Sub-Saharan Africa. World Dev 67:336-362, http://dx.doi.org/10.1016/j.worlddev.2014.10.030

GASHAW B. A. \& KIBRET S. M. (2018). Factors Influencing Farmers' Membership Preferences in Agricultural Cooperatives in Ethiopia. American Journal of Rural Development, 6(3), 94-103.DOI: 10.12691/ajrd-6-3-4

GETNET K \& ANULLO T (2012) Agricultural cooperatives and rural livelihoods: evidence from Ethiopia. Ann Public Coop Econ 83(2):181-198. doi:10.1111/j.1467-8292.2012.00460.x 
GUJARATI, D. (2003). Basic Econometrics. Fourth Edition. Singapura: McGraw-Hill.

IFAD (International Fund for Agricultural Development) (2011) Rural poverty portal., http://www.ruralpovertyportal.org/web/guest/region/home/tags/africa

ILO, Geneva Ma W \& Abdulai A (2016). Does cooperative membership improve household welfare? Evidence from apple farmers in China. Food Policy 58:94-102, http://dx.doi.org/10.1016/j.foodpol.2015.12.002

ITO .J, BAO Z, SU Q, (2012). "Distributional effects of agricultural cooperatives in China: exclusion of smallholders and potential gains on participation," Food Policy 37(6):700-709. http://dx.doi.org/10.1016/j.foodpol.2012.07.009

KASSAHUN G. \& OMER A. (2019). Participatory forest management and smallholder farmers' livelihoods improvement nexus in Northwest Ethiopia. Journal of Sustainable Forestry,38(5), 413-426.DOI: $10.1080 / 10549811.2019 .1569535$

KASSIE M, SHIFERAW B \& MURICHO G (2011). Agricultural technology, crop income, and poverty alleviation in Uganda. World Dev 39(10):1784-1795, http://dx.doi.org/10.1016/j.foodpol.2012.07.009

MARKELOVA H, MWANGI E (2010) Collective action for smallholder market access: evidence and implications for Africa. Rev Policy Res 27(5):621-640. doi:10.1111/j.1541-1338.2010.00462.x

NEGATU B., VERMEULEN R., MEKONNEN, Y. \& KROMHOUT H. (2016). Use of chemical pesticides in Ethiopia: a cross-sectional comparative study on knowledge, attitude and practice of farmers and farm workers in three farming systems. Ann Occup Hyg 60(5):551-566. doi:10.1093/annhyg/mew004

ROSENBAUM P. R. \& RUBIN D. B. (1985) .The bias due to incomplete matching. Biometrics, 41(1), 103-116.

ROSENBAUM PR, RUBIN DB (1983). The central role of the propensity score in observational studies for causal effects. Biometrika 70(1):41-55, https://doi.org/10.1093/biomet/70.1.41

SHIFERAW B, KASSIE M, JALETA M \& YIRGA C (2014). Adoption of improved wheat varieties and impacts on household food security in Ethiopia. Food Policy 44:272-284, http://dx.doi.org/10.1016/j.foodpol.2013.09.012

SIANESI B. (2004). An evaluation of the active labor market programs in Sweden. The Review of Economics and Statistics, 186(1):133-155.http://dx.doi.org/10.1920/wp.ifs.2002.0201

DAGNE, CHRISTIAN F AND TEREFE D. (2015). Social and environmental impacts of agricultural cooperatives: evidence from Ethiopia. https://doi.org/10.1080/13504509.2015.1052860

SPIELMAN DJ, BYERLEE D, ALEMU D, KELEMEWORK D (2010). Policies to promote cereal intensification in Ethiopia: the search for appropriate public and private roles. Food Policy 35(3):185-194, http://dx.doi.org/10.1016/j.foodpol.2009.12.002

TITTONELL P. \& GILLER K. E. (2013). When yield gaps are poverty traps: the paradigm of ecological intensification in African smallholder agriculture. Field Crop Res 143:76-90, http://dx.doi.org/10.1016/j.fcr.2012.10.007

TREBBIN A. (2014). Linking small farmers to modern retail through producer organizations - experiences with producer companies in India. Food Policy 45:35-44, http://dx.doi.org/10.1016/j.foodpol.2013.12.007

UNDP (2015) African economic outlook: Ethiopia.

VERHOFSTADT E, MAERTENS M (2014) Can agricultural cooperatives reduce poverty? Heterogeneous impact of cooperative membership on farmers' welfare in Rwanda. Appl Econ Perspect Policy 37(1):86-106. doi:10.1093/aepp/ppu021

WANYAMA F, DEVELTERE P \& POLLET I. (2008). Encountering the evidence: cooperatives and poverty reduction in Africa. Working papers on social and co-operative entrepreneurship WP-SCE 08-02-2008., http://dx.doi.org/10.2139/ssrn.1330387

ZEWELD N, VAN HUYLENBROECK G. \& BUYSS J. (2013). Household food security through cooperatives in Northern Ethiopia. International Journal of Cooperative Studies, 2(1), 34-44.DOI: $10.11634 / 216826311302358$ 